\title{
Hubungan Kerjasama Perbatasan Indonesia-Malaysia (Studi Kasus Perbatasan Nunukan-Tawau)
}

\author{
Aryono Putra \\ Fakultas Hukum Universitas Borneo Tarakan \\ Jln. Amal Lama Nomor 1, Kota Tarakan Kalimantan Utara \\ aryonoputra.borneo@gmail.com
}

\begin{abstract}
The primary problem in this study is how the decision-making authority for border cooperation with the District Government of Nunukan should get prior approval of the Central Government? Second, what kind of border cooperation that have been undertaken by the Indonesia-Malaysia of North Kalimantan Nunukan Regency to Tawau City of Sabah State? This study uses a normative approach. The results of this study concluded that first, the decision to border cooperation is still dependent on the approval of the Central Government since Regional Authority of Nunukan Regency is very limited. Second, the border cooperation that have been undertaken by the Indonesia-Malaysia of North Borneo Nunukan to Tawau City State of Sabah is the cooperation of the Socio-Economic of Malindo families. However, it does not create an interface connection with the regional development programs and regional economic cooperation such as BIMP-EAGA, which is actually very relevant to be integratively and complementatively developed with the Socio-Economic of Malindo families.
\end{abstract}

Keywords: Border, Indonesia-Malaysia, the socio-economic of Malindo

\begin{abstract}
Abstrak
Permasalahan pada penelitian ini, pertama, bagaimanakah pengambilan keputusan untuk kerjasama perbatasan dengan kewenangan Pemerintah Daerah Kabupaten Nunukan yang harus mendapatkan persetujuan Pemerintah Pusat terlebih dahulu? Kedua, apa bentuk kerjasama perbatasan yang sudah dilaksanakan oleh Indonesia-Malaysia Provinsi Kalimantan Utara Kabupaten Nunukan dengan Kota Tawau Negara Bagian Sabah? Penelitian ini menggunakan pendekatan normatif. Hasil Penelitian ini menyimpulkan, pertama, pengambilan keputusan untuk kerjasama perbatasan masih bergantung dengan persetujuan Pemerintah Pusat. Kewenangan Pemerintah Daerah Kabupaten Nunukan sangat terbatas. Kedua, bentuk kerjasama perbatasan yang sudah dilaksanakan oleh Indonesia-Malaysia Kalimantan Utara Kabupaten Nunukan dengan Kota Tawau Negara Bagian Sabah adalah kerjasama KK Sosek Malindo. Namun, tidak tercipta suatu keterkaitan (interface) dengan program pengembangan kawasan dan kerjasama ekonomi regional seperti BIMP-EAGA, yang sebenarnya sangat relevan untuk dikembangkan secara integratif dan komplementatif dengan KK Sosek Malindo.
\end{abstract}

Kata kunci: Perbatasan, kerjasama Indonesia-Malaysia, sosek Malindo 


\section{Pendahuluan}

Jean-Marc F. Blanchard mengatakan bahwa perbatasan merupakan suatu unit legal-politis yang mempunyai berbagai fungsi unik sekaligus strategis yaitu perbatasan memiliki fungsi militer-strategis, ekonomis konstitutif, identitas, kesatuan nasional, pembangunan negara dan kepentingan domestik. ${ }^{1}$ Tentu saja hal ini harus melibatkan masyarakat perbatasan sebagai objek utamanya.

Pendapat lain di sampaikan oleh Stephen B. Jhones, ${ }^{2}$ bahwa pengelolaan perbatasan negara adalah rangkaian akhir dari proses pembentukan perbatasan. Aspek management (pengelolaan) perbatasan negara merupakan pekerjaan yang bersifat kontinu. Sebab di dalam kegiatan pengelolaan tersebut menyangkut banyak aspek yang terkait dengan pelaksanaan kedaulatan negara itu sendiri, seperti pemeliharaan patok batas negara, lalu lintas orang dan barang, serta persoalan pertahanan dan keamanan negara itu sendiri. Berkaca dari kedua pendapat di atas, sudah sewajarnya bila wilayah perbatasan memerlukan sebuah mekanisme pengelolaan yang terintegrasi dan berkesinambungan karena di ruang perbatasan tersebut akan selalu terjadi "pergesekan" atau interaksi dengan negara tetangga, baik positif maupun negatif. Secara normatif, kawasan perbatasan diatur dalam UndangUndang Nomor 43 Tahun 2008 tentang Wilayah Negara. Pasal 1 ayat (6) menegaskan bahwa, "Kawasan Perbatasan adalah bagian dari Wilayah Negara yang terletak pada sisi dalam sepanjang batas wilayah Indonesia dengan negara lain, dalam hal Batas Wilayah Negara di darat, Kawasan Perbatasan berada di kecamatan.' Sedangkan Undang-Undang Nomor 26 Tahun 2007 tentang Penataan Ruang jo. PP No. 26 Tahun 2008 tentang Rencana Tata Ruang Wilayah Nasional menempatkan kawasan perbatasan, pulau kecil terdepan dan kawasan latihan militer sebagai bagian dari kawasan strategis nasional. Pada penjelasan Pasal 13 ayat (1) PP No. 26 Tahun 2008, ruang lingkup kawasan perbatasan negara, yaitu: (a) Wilayah "Kabupaten/Kota" yang secara geografis dan demografis berbatasan langsung dengan negara tetangga

1 Jean-Marc F. Blanchard, Linking Border Disputes and War: An Institusional-Statist Theory, Geopolitics, No.10, 2005, hlm. 691.

2Sutisna, Lukita, dan Sumaryo, Boundary Making Theory dan Pengelolaan Perbatasan di Indonesia, disampaikan pada Workshop Pengelolaan Wilayah Perbatasan, Jurusan Ilmu HI/UPN Veteran, Yogyakarta, 18 November 2008,hlm. 1-4. 
dan/atau laut lepas; dan (b) Kawasan perbatasan negara meliputi kawasan perbatasan darat dan kawasan perbatasan laut, termasuk pulau-pulau kecil terluar. Berdasarkan regulasi tersebut, kawasan perbatasan memiliki peran penting karena menjadi bagian dari kawasan strategis nasional. Namun faktanya, terdapat sejumlah permasalahan umum yang terjadi hampir di semua kawasan perbatasan wilayah negara Indonesia berupa belum optimalnya pengembangan dan pemanfaatan potensi kawasan perbatasan serta kurang tersedianya sarana/prasarana dasar di kawasan perbatasan. Kondisi ini menyebabkan kawasan perbatasan senantiasa tertinggal dan terisolir, dengan tingkat kesejahteraan masyarakatnya yang rendah dan aksesibilitas yang kurang, terutama akses kawasan perbatasan dengan pusat pemerintahan, pusat-pusat pelayanan publik, atau wilayah lain yang relatif lebih maju. ${ }^{3}$

Sebagai daerah yang memiliki wilayah perbatasan antar negara, provinsi Kalimantan Utara terkenal sebagai daerah transit Tenaga Kerja Indonesia (TKI) ke Malaysia melalui pelabuhan Nunukan dan Sebatik baik yang legal maupun ilegal yang memberikan warna tersendiri dalam hubungan internasional yang disebabkan karena ekses sosial yang ditimbulkannya. ${ }^{4}$

Sementara masyarakat perbatasan Indonesia, umumnya miskin dan secara ekonomi lebih berorientasi ke negara tetangga dengan melakukan migrasi temporer maupun permanen dengan motif utama ekonomi. Hal itu terjadi di sepanjang kawasan perbatasan Kalimantan Utara dengan Kota Tawau Negara Bagian Sabah Malaysia. Ironisnya, stelsel pemerintahan dalam frame hubungan pusat dan daerah tersebut, berdampak serius terhadap design dan implementasi kebijakan pembangunan kawasan perbatasan. Di tingkat pusat misalnya, berdasarkan data dari Dirjen Pemerintahan Umum (PUM) Depdagri, ${ }^{5}$ setidaknya ada 24 instansi yang mengajukan anggaran APBN (Anggaran Pendapatan Belanja Negara) untuk pembangunan kawasan perbatasan dari berbagai perspektif. Kondisi serupa juga terjadi pada level birokrasi Pemerintah Daerah Provinsi Kalimantan Utara vis a vis Pemda Kabupaten yang di dalamnya banyak bersinggungan dengan berbagai dinas

3BPKP2DT, Program Aksi Pengelolaan Perbatasan Antar Negara Kalimantan Timur, Laporan Kajian, BPKP2DT Provinsi Kalimantan Timur, 2012, Samarinda, hlm. 19.

${ }^{4}$ Ibid., hlm. 20.

5Direktorat Jenderal Pemerintahan Umum-Departemen Dalam Negeri, "Perbatasan Antar Negara", Makalahdipresentasikan pada acara Seminar Nasional: Pengelolaan Wilayah Perbatasan Dalam Rangka Menjaga Keutuban Negara Kesatuan Republik Indonesia, diselenggarakan oleh UPN Veteran, Yogyakarta, 18 November 2008, hlm. 4. 
yang sama-sama berkepentingan dengan kawasan perbatasan. Berdasarkan Pasal 8 ayat (2) Undang-Undang Nomor 23 Tahun 2014 tentang Pemerintah Daerah, Pembinaan dan pengawasan oleh Pemerintah Pusat sebagaimana dimaksud dalam Pasal 7 ayat (1) terhadap penyelenggaraan Urusan Pemerintahan oleh Daerah kabupaten/kota dilaksanakan oleh gubernur sebagai wakil Pemerintah Pusat.

Pasal 13 ayat (1) menyebutkan bahwa, "pembagian urusan pemerintahan konkuren antara Pemerintah Pusat dan Daerah provinsi serta Daerah kabupaten/kota sebagaimana dimaksud dalam Pasal 9 ayat (3) didasarkan pada prinsip akuntabilitas, efisiensi, dan eksternalitas, serta kepentingan strategis nasional. (2) Berdasarkan prinsip sebagaimana dimaksud pada ayat (1) kriteria urusan pemerintahan yang menjadi kewenangan Pemerintah Pusat adalah:6 a. Urusan Pemerintahan yang lokasinya lintas Daerah provinsi atau lintas negara; b. Urusan Pemerintahan yang penggunanya lintas Daerah provinsi atau lintas negara; c. Urusan Pemerintahan yang manfaat atau dampak negatifnya lintas Daerah provinsi atau lintas negara; d. Urusan Pemerintahan yang penggunaan sumber dayanya lebih efisien apabila dilakukan oleh Pemerintah Pusat; dan/atau e. Urusan Pemerintahan yang peranannya strategis bagi kepentingan nasional.

Pasal 13 dengan tegas menyerahkan kewenangan pengelolaan kawasan perbatasan menjadi kewenangan pemerintah pusat. Sehingga, sudah bisa dipastikan dalam melaksanakan kerjasama perbatasan Kabupaten Nunukan harus berkordinasi dan mendapatkan persetujuan Pemerintah Pusat.

Dalam pengelolaan wilayah negara dan kawasan perbatasan, pemerintah provinsi berwenang melaksanakan kebijakan Pemerintah dan menetapkan kebijakan lainnya dalam rangka otonomi daerah dan tugas pembantuan, koordinasi pembangunan dikawasan Perbatasan, kerjasama pembangunan kawasan perbatasan antar pemerintah daerah dan/atau dengan pihak ketiga; serta melakukan pengawasan pelaksanaan pembangunan kawasan perbatasan yang dilaksanakan Pemerintah Kabupaten/Kota.7 Sedangkan Pemerintah Kabupaten/Kota berwenang melaksanakan kebijakan Pemerintah dan menetapkan kebijakan lainnya dalam

${ }^{6}$ Pasal 13 Undang-Undang Nomor 23 Tahun 2014 tentang Pemerintah Daerah.

${ }^{7}$ Badan Nasional Pengelola Perbatasan (BNPP) Republik Indonesia, 2011, Desain Besar (Grand Design) Pengelolaan Batas Wilayah Negara dan Kawasan Perbatasan Tabun 2011-2025, Jakarta, hlm. 14. 
rangka otonomi daerah dan tugas pembantuan, menjaga dan memelihara tanda batas, melakukan koordinasi dalam rangka pelaksanaan tugas pembangunan di kawasan perbatasan di wilayahnya; dapat melakukan kerjasama pembangunan kawasan perbatasan antar daerah dan/atau dengan pihak ketiga. Selanjutnya diatur dan ditegaskan, Pemerintah Provinsi dan Pemerintah Kabupaten/Kota berkewajiban menetapkan biaya pembangunan Kawasan yang pelaksanaan kewenangannya perlu diatur lebih lanjut dengan Peraturan Pemerintah.

Melihat kompleksitas persoalan pengelolaan perbatasan tersebut yang pada dasarnya berkutat pada masalah birokrasi yang egosentris, maka benang merah yang bisa disimpulkan sementara adalah adanya keinginan kuat untuk merevitalisasi kawasan perbatasan agar bisa seimbang dengan kemajuan pembangunan di kawasan perbatasan negara tetangga. Namun sayangnya, dalam level tertentu semangat tersebut lebih dimotivasi oleh semangat kompetisi politis yang bersifat reaktif, terutama jika muncul kasus-kasus yang bersinggungan dengan TKI di Malaysia maupun persoalan demarkasi yang tidak kunjung selesai. Padahal, selaras dengan prinsip-prinsip umum yang digariskan oleh Perserikatan Bangsa Bangsa (PBB) maupun pilihan paradigm soft border regime yang dianut Indonesia, maka selayaknya pembangunan perbatasan tersebut memperhatikan kesalingterpengaruhan (interplay) diantara kedua sisi perbatasan, sehingga pendekatannya adalah kerjasama lintas batas.

\section{Rumusan Masalah}

Permasalahan dalam penelitian ini, pertama, bagaimana mekanisme pengambilan keputusan untuk kerjasama perbatasan dengan kewenangan Pemerintah Daerah Kabupaten Nunukan yang harus mendapatkan persetujuan Pemerintah Pusat terlebih dahulu? Kedua, apa saja bentuk kerjasama perbatasan yang sudah dilaksanakan oleh Indonesia-Malaysia Provinsi Kalimantan Utara Kabupaten Nunukan dengan Kota Tawau Negara Bagian Sabah? 


\section{Tujuan Penelitian}

Penelitian ini bertujuan untuk: pertama, mengetahui mekanisme dalam mengambil keputusan untuk kerjasama perbatasan dengan kewenangan Pemerintah Daerah Kabupaten Nunukan yang harus mendapatkan persetujuan Pemerintah Pusat; Kedua, mengetahui dan menganalisis bentuk kerjasama perbatasan IndonesiaMalaysia dalam wilayah Kabupaten Nunukan Provinsi Kalimantan Utara dengan Kota Tawau Negara Bagian Sabah dalam percepatan pembangunan kawasan perbatasan kedua negara.

\section{Metode Penelitian}

Penelitian ini menggunakan jenis penelitian normatif. Dalam konteks ini, kebijakan yang dikaji adalah kebijakan pemerintah dalam pembangunan kawasan perbatasan dengan mengambil studi kasus di Provinsi Kalimantan Utara Kabupaten Nunukan yang berbatasan dengan Kota Tawau Negara Bagian Sabah Malaysia. Untuk melengkapi bahan-bahan riset, maka digunakan dua jenis data, yakni data primer yang digali dari lapangan dengan pihak yang bersinggungan secara langsung atau tidak langsung dengan penelitian ini. Selain itu, digunakan juga data sekunder berupa peraturan perundang-undangan dan hasil kajian sejenis baik di tingkat nasional maupun internasional. Data yang telah diperoleh di analisis secara deskriptif kualitatif.

\section{Hasil Penelitian dan Pembahasan}

\section{Sejarah Hubungan Kerjasama Indonesia-Malaysia}

Tidak semua persoalan antara Indonesia dengan Malaysia dapat diselesaikan dengan jalan militer untuk mencapai suatu penyelesaian. Kebanyakan untuk menyelesaikan permasalahan, Indonesia dengan Malaysia melakukan hubungan diplomasi untuk membicarakan dan melakukan lobi-lobi menyangkut permasalahan yang dihadapi kedua negara. Dengan kata lain dapat dikatakan bahwa dalam proses perkembangannya tampak adanya dinamika perkembangan masyarakat yang 
dicirikan pula oleh adanya ketegangan dan konflik yang muncul selain kerjasama di antara mereka. 8

Sejak 1995, lingkup wilayah kerjasama Sosial Ekonomi Kaltim, dalam rangka penyelenggaraan Kerjasama Luar Negeri Malaysia-Indonesia, hanyalah Negara Bagian Sabah. Kawasan perbatasan yang aktif berpartisipasi dalam kerjasama ini adalah sebagian kecamatan perbatasan di Kabupaten Nunukan, sedangkan lainnya seperti Kabupaten Malinau dan Kubar, kecamatan-kecamatan perbatasannya belum termasuk. Namun sejak melalui beberapa kali pengusulan, dan pembahasan di beberapa pertemuan antara JKK/KK Sosek Malindo Pusat, Indonesia-Malaysia akhirnya kecamatan-kecamatan tersebut untuk sementara dapat pula dimasukkan, yang bukan hanya antara Provinsi dengan Negara Bagian Sabah, tetapi juga dengan Negara Bagian Serawak.

Adapun Tugas dan Fungsi Kelompok Kerja Sosek Tingkat Daerah/Negeri: 1. menentukan proyek-proyek yang akan membawa keseimbangan pembangunan dan keselamatan/keamanan di wilayah perbatasan bersama; 2. menentukan proyek-proyek di Provinsi daerah/ negeri yang mendatangkan manfaat bagi kedua belah dan boleh dipergunakan secara bersama; 3. menentukan proyek-proyek bersama; 4. merencanakan cara-cara pelaksanaan pembangunan sosial ekonomi daerah perbatasan provinsi daerah tingkat/negeri msing-masing sesuai dengan ketentuan yang ditetapkan oleh kelompok kerja ditingkat pusat; 5. melaksanakan pertukaran informasi mengenai proyek-proyek pembangunan sosio ekonomi di daerah perbatasan bersama; 6. menyampaikan KK dan laporan kepada Kelompok Kerja Bersama tingkat Pusat mengenai pelaksanaan Pembangunan Sosio Ekonomi Perbatasan Indonesia-Malaysia. Sebanyak tujuh kertas kerja dibahas dalam Rapat Teknis ke-18 Kelompok Kerja/Jawatan Kusa Kerja Pembangunan Sosial Ekonomi (KK/JKK Sosek Malindo) Tingkat Provinsi Kalimantan Timur/Peringkat Sabah, yaitu: ${ }^{9}$ pembangunan Pos Lintas Batas Laut (PLBL), Pembangunan Pos Lintas Batas Darat (PLBD), Pencegahan/ Penanggulanagan Penyelundupan, Kerjasama

8 I Ketut ardhana, Studi Perbatasan Antara Indonesia dan Malaysia: Globalisme dan Lokalisme, Makalah dipresentasikan pada Konferensi Nasional Sejarah IX dan Kongres MSI yang diadakan di Hotel Bidakara, Jakarta pada tanggal 5-8 Juli 2011, hlm. 11-12.

${ }_{9}$ http://www.kaltimprov.go.id/berita-kkjkk-sosek-malindo-bahas-7-kertas-kerja.html, diakses pada 12 Mei 2015. 
Hubungan Sosial, Kerjasama Bidang Pendidikan, Kerjasama Bidang Kesehatan, dan Kerjasama Bidang Ekonomi dan Perdagangan.

\section{Mekanisme Pengambilan Keputusan Kerjasama Perbatasan}

Dalam 5 tahun terakhir, isu perbatasan di tingkat nasional telah menjadi isu strategis karena menyangkut kedaulatan negara dan martabat bangsa. Menguatnya isu perbatasan disebabkan adanya berbagai ancaman yang timbul di seluruh wilayah perbatasan Indonesia baik di bidang politik, ekonomi, sosial budaya, maupun pertahanan dan keamanan wilayah. Sejarah telah mencatat bahwa kasus pulau Sipadan dan Ligitan merupakan pelajaran yang berharga bagi pemerintah Indonesia untuk merubah paradigma lama yang memandang wilayah perbatasan dengan sebagai halaman belakang, dan memulai dengan paradigma baru yang melihat wilayah perbatasan sebagai beranda depan negara (frontier area). Sengketa blok Ambalat di perairan wilayah Kalimantan Timur dengan Malaysia menjadi ancaman jilid kedua setelah Malaysia sukses menguasai Pulau Sipadan dan Ligitan. Ancaman tersebut tidak boleh dipandang sebelah mata mengingat Blok Ambalat mengandung potensi sumber daya minyak yang disinyalir cukup besar yang merupakan faktor yang sangat menarik (pull factor) untuk menguasainya.

Kesadaran terhadap pentingnya percepatan pembangunan di wilayah perbatasan mulai terlihat dalam RPJM Nasional 2005-2009 yang menempatkan pembangunan wilayah perbatasan antar negara sebagai salah satu prioritas pembangunan nasional. Dengan dikeluarkannya Undang-Undang Nomor 43 Tahun 2008 tentang Wilayah Negara, untuk mengelola batas wilayah negara dan mengelola kawasan perbatasan pada tingkat pusat dan daerah, pemerintah dan pemerintah daerah membentuk Badan Pengelola Nasional dan Badan Pengelola Daerah. ${ }^{10}$ Sebagai tindak lanjut dari undang-undang tersebut, Gubernur Kalimantan Timur mengeluarkan Peraturan Gubernur Nomor 13 Tahun 2009 Tentang Organisasi dan Tata Kerja Badan Pengelolaan Kawasan Perbatasan, Pedalaman, dan Daerah Tertinggal Provinsi Kalimantan Timur. Selain itu, Gubernur telah

\footnotetext{
${ }^{10}$ Lihat juga Peraturan Presiden Republik Indonesia Nomor 12 Tahun 2010 tentang Badan Nasional Pengelola Perbatasan.
} 
meminta Pemerintah Kabupaten yang memiliki wilayah perbatasan, dapat segera membentuk Badan Pengelolaan Kawasan Perbatasan Kabupaten mengacu kepada Undang-Undang Nomor 43 Tahun 2008 tentang Wilayah Negara. Rangkaian peraturan perundang-undangan tersebut di atas merupakan suatu bentuk komitmen konstitusional yang perlu ditindaklanjuti dengan implementasi program secara konsisten dan konsekuen. Hal ini mengingat bahwa permasalahan wilayah perbatasan antar negara sangat kompleks, karena selain masalah pertahanan dan keamanan teritorial yang demikian luas, juga yang tidak kalah pentingnya adalah masalah peningkatan kesejahteraan masyarakat di wilayah perbatasan yang pada umumnya masih terisolasi, tertinggal dan hidup di bawah garis kemiskinan. Sehubungan dengan hal tersebut pemerintah provinsi Kalimantan Timur sudah mempunyai komitmen untuk memberi perhatian penuh terhadap pembangunan kawasan perbatasan yang tercermin dalam dalam Rencana Pembangunan Jangka Menengah (RPJM) Provinsi Kalimantan Timur 2009 - 2013 yang menempatkan masalah perbatasan dalam salah satu skala prioritas pembangunan Kalimantan Timur 2009-2013.11

Berdasarkan Pasal 13 ayat (3) sebagaimana dimaksud pada ayat (1) kriteria Urusan Pemerintahan yang menjadi kewenangan Daerah provinsi adalah:12 a. Urusan Pemerintahan yang lokasinya lintas Daerah kabupaten/kota; b. Urusan Pemerintahan yang penggunanya lintas Daerah kabupaten/kota; c. Urusan Pemerintahan yang manfaat atau dampak negatifnya lintas Daerah kabupaten/kota; dan/atau d. Urusan Pemerintahan yang penggunaan sumber dayanya lebih efisien apabila dilakukan oleh Daerah Provinsi.

Dalam pengaturan Pasal 13 ayat (4) Berdasarkan prinsip sebagaimana dimaksud pada ayat (1) kriteria Urusan Pemerintahan yang menjadi kewenangan Daerah kabupaten/kota adalah: ${ }^{13}$ a. Urusan Pemerintahan yang lokasinya dalam Daerah kabupaten/kota; b. Urusan Pemerintahan yang penggunanya dalam Daerah kabupaten/kota; c. Urusan Pemerintahan yang manfaat atau dampak negatifnya hanya dalam Daerah kabupaten/kota; dan/atau d. Urusan Pemerintahan yang

${ }^{11}$ Konsekuensi yang harus dipikul oleh Pemerintah dan Pemerintah daerah (Kabupaten Nunukan) adalah menyediakan anggaran secara khusus, rasional, dan berkelanjutan.

12 Pasal 13 ayat (3) Undang-Undang Nomor 23 Tahun 2014 tentang Pemerintah Daerah.

13 Pasal 13 ayat (4) Undang-Undang Nomor 23 Tahun 2014 tentang Pemerintah Daerah. 
penggunaan sumber dayanya lebih efisien apabila dilakukan oleh Daerah kabupaten/kota.

Selanjutnya dalam Pasal 15 ayat (4) Perubahan terhadap pembagian urusan pemerintahan konkuren antara Pemerintah Pusat dan Daerah provinsi dan Daerah kabupaten/kota sebagaimana dimaksud pada ayat (1) yang tidak berakibat terhadap pengalihan urusan pemerintahan konkuren pada tingkatan atau susunan pemerintahan yang lain ditetapkan dengan peraturan pemerintah. ${ }^{14}$

Pasal 16 ayat (1) Pemerintah Pusat dalam menyelenggarakan urusan pemerintahan konkuren sebagaimana dimaksud dalam Pasal 9 ayat (3) berwenang untuk:15 a. menetapkan norma, standar, prosedur, dan criteria dalam rangka penyelenggaraan Urusan Pemerintahan; dan b. melaksanakan pembinaan dan pengawasan terhadap penyelenggaraan Urusan Pemerintahan yang menjadi kewenangan Daerah.

Dalam pengaturan Pasal 16 ayat (2) norma, standar, prosedur, dan kriteria sebagaimana dimaksud pada ayat (1) huruf a berupa ketentuan peraturan perundangundangan yang ditetapkan oleh Pemerintah Pusat sebagai pedoman dalam penyelenggaraan urusan pemerintahan konkuren yang menjadi kewenangan Pemerintah Pusat dan yang menjadi kewenangan Daerah. (3) Kewenangan Pemerintah Pusat sebagaimana dimaksud pada ayat (1) dilaksanakan oleh kementerian dan lembaga pemerintah non kementerian. (4) Pelaksanaan kewenangan yang dilakukan oleh lembaga pemerintah non kementerian sebagaimana dimaksud pada ayat (3) harus dikoordinasikan dengan kementerian terkait. (5) Penetapan norma, standar, prosedur, dan criteria sebagaimana dimaksud pada ayat (1) huruf a dilakukan paling lama 2 (dua) tahun terhitung sejak peraturan pemerintah mengenai pelaksanaan urusan pemerintahan konkuren diundangkan. ${ }^{16}$

Dalam pengaturan Pasal 17 ayat (1) Daerah berhak menetapkan kebijakan Daerah untuk menyelenggarakan Urusan Pemerintahan yang menjadi kewenangan Daerah. ${ }^{17}$ Dengan pengaturan pasal ini menunjukan bahwa daerah Kabupaten

\footnotetext{
14 Pasal 15 ayat (4) Undang-Undang Nomor 23 Tahun 2014 tentang Pemerintah Daerah.

15 Pasal 16 ayat (1) Undang-Undang Nomor 23 Tahun 2014 tentang Pemerintah Daerah.

${ }^{16}$ Dalam pengaturan pasal ini dapat diartikan bahwa secara teknis pengelolaan perbatasan bukan menjadi kewenangan Kabupaten Nunukan tetapi menjadi kewenangan pemerintah pusat.

17 Pasal 17 ayat (1) Undang-Undang Nomor 23 Tahun 2014 tentang Pemerintah Daerah.
} 
Nunukan tidak memiliki kewenangan seperti Kota Tawau Negara Bagian Malaysia yang lebih besar dalam pengelolaan perbatasan Negara dalam hal ini kerjasama antara negara. ${ }^{18}$

Pengelolaan kawasan perbatasan mencakup pengelolaan potensi sumber daya kawasan perbatasan baik sumber daya manusia (SDM) maupun sumber daya alam (SDA) sebagai modal dasar pembangunan dan pengembangan wilayah perbatasan. Pengelolaan kawasan perbatasan dilaksanakan secara bersama-sama baik oleh pemerintah, pemerintah daerah menurut kewenangan yang telah diatur dalam peraturan perundangan yang berlaku.

Menurut data Departemen Luar Negeri Republik Indonesia pada 2003, perjuangan heroik dan bersejarah bagi negara kepulauan Bagi Indonesia tercermin atas Pulau Sipadan dan Ligitan melalui Pengadilan Internasional di DenHaag, Belanda, ternyata hasilnya tidak seperti yang diharapkan. Peristiwa tersebut merupakan pengalaman berharga bagi bangsa Indonesia, meskipun perundingan perbatasan tentang landas kontinen Indonesia-Malaysia yang terkait dengan Pulau Sipadan dan Ligitan telah dimulai sejak 1969.19

Konfrontasi antara Indonesia dan Malaysia pada 1963 merupakan pukulan berat bagi rakyat Indonesia dikawasan Pulau Sebatik, Nunukan, Tarakan di Kalimantan Timur. Hubungan ekonomi dengan Malaysia terputus sehingga dalam kegiatan-kegiatan perdagangan menjadi memanas. Kapal-kapal seperti (padau) sejenis perahu atau sampan, yang dikenal dengan istilah "Semokol", dilarang.

Konflik memuncak ketika pada 17 September 1963 Pemerintah Indonesia memutuskan hubungan diplomatik dengan Malaysia dan dilanjutkan dengan pemutusan lalu lintas ekonomi dengan Malaysia dan Singapura. Konflik ini disebabkan laporan pelaksanaan misi tidak sah dan tidak sesuai dengan prosedur yang telah ditentukan oleh KTT (Konfrensi Tingkat Tinggi) Manila. Dengan semakin meruncingnya ketegangan antara kedua negara dan keadaan semakin memburuk disebabkan oleh adanya pernyataan dari Presiden RI Soekarno tentang

18 Lihat juga Peraturan Pemerintah Republik Indonesia Nomor 79 Tahun 2005 tentang Pedoman Pembinaan dan Pengawasan Atas Penyelenggaraan Pemerintah Daerah.

${ }_{19}$ Mustafa Abu Bakar, Menata Pulau-Pulau Kecil Perbatasan (Belajar dari kasus Sipadan, Ligitan dan Pulau Sebatik), Penerbit Buku Kompas, Jakarta, 2006, hlm. 1. 
rencana untuk membantu rakyat Kalimantan Utara yang tidak menyetujui Federasi Malaysia.

Dampak dari penyataan Presiden RI adalah keluarnya ucapan dari Presiden RI tentang pelaksanaan komando aksi relawan yang lebih dikenal dengan sebutan Dwikora (Dwi Komando Rakyat). Dari pernyataan ini dapat disimpulkan bahwa Presiden Soekarno memperkuat ketahanan Resolusi Indonesia dan membantu pelaksanaan perjuangan revolusioner rakyat Malaysia, Singapura, Sabah, Sarawak, dan Brunei Darussalam untuk membubarkan negara Malaysia.

Dalam hubungan Internasional, perkembangan kedua negara Indonesia dan Malaysia. Meskipun, sempat terjadi ketegangan yang berakhir pada 1968, namun pada 27 Oktober 1969. ${ }^{20}$ Dengan maksud untuk memperkuat tali persahabatan sejarah antara kedua negara, kemudian sepakat dalam perjanjian Tentang Penetapan Garis Batas Landas Kontinen Antara Kedua Negara. Dengan isi perjanjian yang terdiri dari 6 Pasal. Bertindak dan mewakili masing-masing Negara dalam perjanjian itu untuk Pemerintah Republik Indonesia yaitu Prof. Dr. Ir. Soemantri Brodjonegoro (Menteri Pertambangan Republik Indonesia), sedangkan untuk Pemerintah Malaysia yaitu Tan Sri Abdul Kadir Bin Yusuf (Peguan Negara Malaysia).

Pada 1967, Menteri Pertahanan dan Keamanan menetapkan hak pengusahaan hutan kepada Jajasan Maju Kerja (PT Jamaker), sebuah yayasan yang didirikan ABRI. Yayasan ini mengelola hutan 843.500 ha di Kalimantan Barat dan 265.000 ha di Kalimantan Timur. ${ }^{21}$ Kenikmatan dalam mengelola hutan membuat lupa akan tugas utama menjaga kedaulatan negara di perbatasan. Secara fisik, postur pertahanan di kawasan perbatasan yang diwujudkan dalam pos militer perbatasan amat memperihatinkan. Ini amat kontras dengan pertahanan kawasan perbatasan Malaysia yang secara fisik amat memadai.

Korelasi ini, baik positif maupun negatif, harus dipahami dalam konteks perubahan-perubahan yang terjadi pada masyarakat di Indonesia. Kemampuan dan keberhasilan pemerintah dalam mengatasi efek dari perubahan-perubahan ini

${ }^{20}$ Lihat Dalam Naskah Surat Perjanjian atau Persetujuan Antara Pemerintah Republik Indonesia Dan Pemerintah Malaysia Tentang Penetapan Garis Batas Landas Kontinen Antara Kedua Negara di buat pada tanggal 27 Oktober 1969 di Kuala Lumpur Malaysia disalin dalam tiga bahasa yaitu bahasa Inggris, Indonesia, Malaysia. Di tegaskan dalam hal terdapat ketidaksesuaian pengertian antara naskah-naskah, Maka naskah Inggris yang menentukan.

${ }^{21}$ Ibid., Taufik Adi susilo, hlm. 98. 
akan menjadi alat ukur untuk mengetahui konsep negara hukum, yang juga sebagai negara kepulauan di Indonesia.

Mengenai wilayah Republik Indonesia alinea keempat Pembukaan UUD 1945 hanya menyebut sebagai "seluruh tumpah darah Indonesia". Dalam sidang-sidang BUPKI terdapat tiga aliran pemikiran mengenai batas-batas negara, yaitu:22 (a) Memandang batasnya ialah wilayah Hindia Belanda dahulu; (b) Wilayah Hindia ditambah Papua ditambah Timor dan kepulauan di sekelilingnya; (c) Wilayah Hindia Belanda dahulu ditambah Borneo Utara ditambah Timor semuanya.

\section{Bentuk Kerjasama Indonesia-Malaysia Kabupaten Nunukan-Tawau}

UUD 1945 sebagai landasan konstitusional pada pembukaannya telah mengamanatkan bahwa negara berkewajiban melindungi segenap bangsa Indonesia dan seluruh tumpah darah Indonesia, memajukan kesejahteraan umum, mencerdaskan kehidupan bangsa, dan ikut melaksanakan ketertiban dunia yang berdasarkan kemerdekaan, perdamaian abadi dan keadilan sosial.

Dengan paradigma baru yang menyebutkan bahwa kawasan perbatasan antar negara adalah beranda depan negara, maka dengan demikian masyarakat yang tinggal di kawasan perbatasan baik perbatasan laut maupun perbatasan darat keberadaannya menjadi sangat penting dalam hubungan antar negara, karena mereka berinteraksi secara langsung, baik dalam hubungan sosial maupun ekonomi. Sehubungan dengan hal tersebut, maka pemerintah perlu meningkatkan kecerdasan masyarakat perbatasan agar memiliki daya saing dalam pergaulan internasional dan persaingan dalam globalisasi. ${ }^{23}$

Hubungan Malaysia-Indonesia terjalin melalui dua saluran utama yaitu secara bilateral dan melalui ASEAN. Dalam hal ini, hubungan ekonomi melalui ASEAN dilihat sangat signifikan dalam pembangunan ekonomi kedua negara ini. Salah satu daripada kerjasama antara negara-negara ASEAN yang turut melibatkan Malaysia dan Indonesia dalam kerjasama ini adalah Kawasan Perdagangan Bebas ASEAN atau

${ }^{22}$ Yudha Bhakti Ardhiwisastra, Imunitas Kedaulatan Negara di Forum Pengadilan Asing, Alumni, Bandung, 1991, hlm. 64.

${ }^{23}$ Undang-Undang Nomor 17 Ketetapan Majelis Permusyawaratan Rakyat Republik Indonesia Nomor VII/MPR/2001 tentang Visi dan Misi Indonesia Masa Depan. 
ASEAN Free Trade Area (AFTA). ${ }^{24}$ Persetujuan ini dicapai pada 1992 apabila negaranegara ini menyetujui untuk mengurangkan tarif perdagangan di kalangan negaranegara ini yang bermula pada 2003.25 Walau bagaimanapun, ia terhadap kepada 6 negara awal yang menyertai ASEAN termasuk Indonesia dan Malaysia. Manakala negara-negara lain yang baru menyertai ASEAN akan memulakannya agak lewat dalam memberikan peluang kepada Negara-negara ini bersedia untuk menyertai perdagangan bebas. ${ }^{26}$

Pembagian kewenangan antara pemerintah pusat dan pemerintah daerah masih belum jelas. ${ }^{27}$ Kewenangan daerah masih banyak yang belum didesentralisasikan karena peraturan dan perundangan sektoral yang masih belum disesuaikan dengan Undang-Undang tentang Pemerintahan Daerah. Hal ini mengakibatkan berbagai permasalahan, yaitu antara lain dalam hal kewenangan, pengelolaan APBD, pengelolaan suatu kawasan tertentu, hubungan eksekutif dan legislatif daerah, pengaturan pembagian hasil sumberdaya alam dan pajak, dan lainnya. Selain itu juga menimbulkan tumpang tindih kewenangan antar pusat, provinsi dan daerah yang mengakibatkan berbagai permasalahan dan konflik antar berbagai pihak dalam pelaksanaan suatu aturan, misalnya tentang pendidikan, tenaga kerja, pekerjaan umum, pertanahan, penanaman modal, serta kehutanan dan pertambangan.

Masih rendahnya kerjasama antar daerah dalam penyediaan pelayanan publik dan peningkatan kesejahteraan masyarakat. Kewenangan yang besar dalam pelayanan masyarakat belum diringi dengan pelaksanaan yang baik terutama pelayanan masyarakat di wilayah terpencil yang berbatasan antar daerah. Belum banyak kerjasama antar daerah yang dilaksanakan dalam penyediaan pelayanan publik terutama di daerah-daerah perbatasan antar kota, antar daerah, antar provinsi dan antar

${ }^{24}$ Selain AFTA, negara-negara ASEAN juga pernah berusaha untuk meningkatkan kerjasama dalam berbagai bidang misalnya melalui Preferential Trading Agreement (PTA) atau PerjanjianPeraturan Keistimewaan Perdagangan yang diperkenalkan pada 1977.

${ }^{25}$ Semasa sidang tertinggi negara ASEAN di Singapura pada 1992, enam buah negaraASEAN yaitu Brunei, Indonesia, Malaysia, Filipina, Singapura dan Thailand setuju memulai usaha mengadakan AFTA, yaitu pengurangan tarif bagi perdagangan negaranegaraASEAN pada 2008.

26Vietnam akan hanya bermula pada pada 2006, Laos dan Myanmar (2007) dan Kamboja (2010).

${ }^{27}$ Kehadiran BNPP di tingkat Pusat, di tingkat daerah BPKP2DT di Provinsi Kalimantan Timur, dan BPP-D di Kabupaten Nunukan, Kabupaten Malinau, Kabupaten Kutai Barat yang mengkoordinasikan pengelolaan perbatasan di tingkat nasional dan daerah. Penanganan perbatasan masih bersifat parsial dan ad hoc sehingga tidak optimal. 
negara. Perhatian pemerintah daerah lebih banyak ditujukan bagi kepentingan prioritas wilayahnya masing-masing yang mengakibatkan terabaikannya kesejahteraan masyarakat di daerah perbatasan tersebut.

Dalam UUD Republik Indonesia Tahun 1945 yang berbunyi sebagaimana: 1) Pasal 18 ayat (2): Pemerintah daerah Provinsi, daerah Kabupaten, dan daerah Kota mengatur dan mengurus sendiri urusan pemerintahan menurut asas otonomi dan tugas pembantuan; 2) Pasal 18 ayat (6) Pemerintahan daerah berhak menetapkan peraturan daerah dan peraturan-peraturan lain untuk melaksanakan otonomi dan tugas pembantuan.

Meski kondisi masyarakat di perbatasan sangat memprihatinkan, melingkupi kebodohan, kemiskinan, keterisolasian, tertinggal, terbelakang dan termarjinalkan, namun para pemangku kepentingan seakan saling lempar tanggung jawab. Antara pemerintah pusat, pemerintah provinsi dan pemerintah kabupaten sepertinya tidak memiliki simpul keterpaduan yang mengintergrasikan antara kebijakan dan implementasi. Koordinasi dan sinergi dalam program pembangunan akhirnya menyisakan pilihan bergantung kepada negara tetangga.

Perdebatan dan penjualan kawasan perbatasan melalui media masa dan elektronik saat ini cukup ramai dibicarakan, perbatasan baik keamanan dan pertahanan negara, aspek ekonomi, hukum, politik dan pranata sosial ketergantungan masyarakat perbatasan pada kehadiran negara sampai pada kedaulatan negara, namun hal ini tidaklah cukup bagi masyarakat perbatasan. Karena konsep otonomi daerah dan cita-cita menciptakaan masyarakat perbatasan yang sejahtera selalu tersandra oleh kewenangan yang melibatkan hubunganhubungan kekuasaan yang timpang, tarik menarik antara pusat dan daerah.

Dalam pembahasan otonomi daerah yang relevansinya dengan konsep desentralisasi ${ }^{28}$ menurut Maurice Duverger mengatakan, di dalam komunitaskomunitas besar, pertarungan politik yang riil di dalam lingkaran dalam dilaksanakan oleh mesin-mesin politik yang besar dan organisasi-organisasiorganisasi politik yang besar, di mana warga negara rata-rata mengambil bagian hanya secara abstrak dan episodik. Rasa aliensi (sense of alienation) sebagai akibat

${ }^{28}$ Maurice Duverger, Penerjemah: Daniel Dhakidae, Sosiologi Politik, Ed, 1, Cetakan 6, PT. Raja Grafindo Persada, Jakarta, 1998, hlm. 56-57. 
hanya sebagian saja terusir oleh personalisasi kekuasaan, karena dia memegang karakter ilusif. Partisipasi asli oleh para warga di dalam mencapai keputusan mungkin hanya bilamana komunitas dibagi menjadi kelompok-kelompok yang lebih kecil, kelompok-kelompok yang diorganisir atas skala manusiawi dan dengan kekuasaan, otoritas dan alat untuk membuat keputusan. Inilah yang dimaksudkan dengan "desentralisasi".

Lebih lanjut Maurice menjelaskan, desentralisasi janganlah dikaburkan dengan pengaturan kekuasaan secara regional. Bahkan di dalam pemerintahan yang sentralistis ada kebutuhan bagi kekuasaan untuk memiliki markas-markas lokalnya. Akan tetapi kantor-kantor regional ini tidak memasukan satu pun kehidupan politik, apakah mereka berada di dalam tangan agen-agen administratif biasa, yang melaksanakan keputusan yang dibuat ibukota, atau apakah mereka berada dalam tangan-tangan orang-orang yang diberikan kekuasaan mengambil keputusan, yang mereka lakukan atas nama pemerintah pusat, satu-satunya badan kemana mereka bertanggungjawab (prefect di Perancis misalnya). Kehidupan politik lokal hanya hidup bilamana kekuasaan lokal independen dari kekuasaan pusat.

\section{Penutup}

Berdasarkan uraian di atas dapat disimpulkan, pertama, kesenjangan dan ketimpangan pembangunan (disparity) yang ditandai dengan adanya kesenjangan pembangunan antara kawasan perbatasan dengan kawasan lain di luar kawasan perbatasan dan kawasan perbatasan di negara tetangga. Pusat pembangunan industri berkembang pada kawasan pantai, sehingga perekonomian di kawasan tersebut tumbuh dengan cepat, sementara itu di kawasan perbatasan dan pedalaman masih bertumpu pada sektor pertanian tradisional dengan produktivitas yang sangat terbatas belum banyak terjadi perubahan, sehingga kawasan perbatasan menjadi daerah tertinggal sebagaimana yang tertuang dalam RPJM Nasional 2009-2014, yang menetapkan 3 kabupaten di Kalimantan Timur yaitu: Kabupaten Kutai Barat, Malinau dan Nunukan sebagai daerah tertinggal bersama-sama dengan 183 Kabupaten lainnya di Indonesia. 
Komitmen pemerintah (goodwill) baik pemerintah pusat maupun pemerintah daerah sangat kuat untuk mendorong percepatan pembangunan di perbatasan sebagai halaman depan negara Republik Indonesia. Hal ini dibuktikan dengan keluarnya Undang-Undang Nomor 43 Tahun 2008 tentang Wilayah Negara yang pada intinya perlu dibentuk lembaga pengelolaan kawasan perbatasan baik di tingkat pusat maupun daerah. Sebagai tindak lanjut dari amanat undangundang tersebut, di provinsi Kalimantan Timur telah di bentuk Badan pengelolaan Kawasan Perbatasan, Pedalaman dan Daerah Terpencil berdasarkan Peraturan Gubernur Kalimantan Timur Nomor 13 Tahun 2009 tentang organisasi dan tata kerja Badan Pengelolaan Kawasan Perbatasan, Pedalaman, dan Daerah Tertinggal Provinsi Kalimantan Timur. Pada tingkat pemerintah provinsi Kalimantan Timur, komitmen tersebut sudah dituangkan dalam Rencana Pembangunan Jangka Menengah (RPJM) provinsi Kalimanatan Timur 2009-2013 yang menempatkan perbatasan sebagai salah satu isu strategis di Provinsi Kalimantan Timur.

Demikian pula halnya pada tingkat nasional yang tertuang dalam RPJM Nasional 2010-2014 juga menempatkan pembangunan wilayah perbatasan sebagai salah satu isu strategis dan program prioritas dalam rangka mewujudkan kawasan perbatsan sebagai beranda depan negara RI, dan sebagai pintu gerbang aktivitas ekonomi dan perdagangan dengan negara tetangga.

Selanjutnya telah dibentuk pula Badan Nasional Pengelola Perbatasan dengan Peraturan Presiden Nomor 12 Tahun 2009 yang semakin menunjukkan semaikin menguatnya keinginan untuk membangun wilayah perbatasan sebagai beranda depan negara Republik Indonesia.

Peraturan Presiden No. 78 Tahun 2005 mengenai pulau-pula kecil terluar yang mengamanatkan pengelolaan pulau-pulau kecil terluar dalam aspek keamanan, kesejahteraan, dan lingkungan. Undang-Undang Nomor 26 Tahun 2007 tentang penataan ruang juga telah menetapkan kawasan perbatasan sebagai kawasan strategis dari sudut pandang pertahanan dan keamanan yang diprioritaskan penataan ruangnya. Peraturan Pemerintah Nomor 26 Tahun 2008 tentang Rencana Tata Ruang Wilayah Nasional telah menetapkan 26 Pusat Kegiatan Strategis Nasional (PKSN) sebagai kota utama kawasan perbatasan yang perlu dipercepat pembangunannya selama 10 tahun kedepan. Dengan diterbitkannya Peraturan Pemerintah Nomor 12 
Tahun 2010 tentang Badan Pengelola Kawasan Perbatasan, memberikan keyakinan tentang komitmen pemerintah untuk meningkatkan percepatan pembangunan kawasan perbatasan antar negara di Kalimantan Timur pada khususnya dan di Indonesia pada umumnya.

\section{Daftar Pustaka}

Abu Bakar, Mustafa, Menata Pulau-Pulau Kecil Perbatasan (Belajar dari kasus Sipadan, Ligitan dan Pulau Sebatik), Jakarta, Penerbit Buku Kompas, 2006.

Adi Susilo, Taufik, (Editor: Azis Safa), Indonesia VS Malaysia: (Membandingkan Peta Kekuatan Indonesia Dan Malaysia, Jogjakarta: Garasi, Cetakan I, Juni 2009.

BPKP2DT, Program Aksi Pengelolaan Perbatasan Antar Negara Kalimantan Timur. Laporan Kajian, BPKP2DT Provinsi Kalimantan Timur, Samarinda, 2012.

Badan Nasional Pengelola Perbatasan (BNPP) Republik Indonesia, Desain Besar (Grand Design) Pengelolaan Batas Wilayah Negara dan Kawasan Perbatasan Tahun 2011-2025, Jakarta, 2011.

Bhakti Ardhiwisastra, Yudha, Imunitas Kedaulatan Negara di Forum Pengadilan Asing, Alumni, Bandung, 1991.

Direktorat Jenderal Pemerintahan Umum-Departemen Dalam Negeri, "Perbatasan Antar Negara", Makalah dipresentasikan pada acara Seminar Nasional: Pengelolaan Wilayah Perbatasan Dalam Rangka Menjaga Keutuhan Negara Kesatuan Republik Indonesia, diselenggarakan oleh UPN Veteran, Yogyakarta.

Duverger, Maurice, Penerjemah: Daniel Dhakidae, Sosiologi Politik, Ed, 1. Cetakan 6. Jakarta: PT. RajaGrafindo Persada, April 1998.

F. Blanchard, Jean-Marc, Linking Border Disputes and War: An Institusional-Statist Theory, Geopolitics, No.10, 2005.

Guo, Border-Regional Economics. Heidelberg, Physica-Verl; Germany, 1996.

Ketut Ardhana, I., Studi Perbatasan Antara Indonesia dan Malaysia: Globalisme dan Lokalisme, Makalah dipresentasikan pada Konferensi Nasional Sejarah IX dan Kongres MSI yang diadakan di Hotel Bidakara, Jakarta pada 5-8 Juli 2011.

Lapian, Adrian B. Orang Laut-Bajak Laut-Raja Laut; Sejarah Kawasan Laut Sulawesi Abad XIX, Komunitas Bambu; Cetakan Pertama, Jakarta, 2009.

Naskah Surat Perjanjian atau Persetujuan Antara Pemerintah Republik Indonesia Dan Pemerintah Malaysia Tentang Penetapan Garis Batas Landas Kontinen Antara Kedua Negara di buat pada tanggal 27 Oktober 1969 di Kuala Lumpur Malaysia. 
Sutisna, Lukita, dan Sumaryo, Boundary Making Theory dan Pengelolaan Perbatasan di Indonesia, Disampaikan pada Workshop Pengelolaan Wilayah Perbatasan, Jurusan Ilmu HI/UPN Veteran, Yogyakarta, 18 November 2008.

Makalah: Wakil Kepala Staf TNI Angkatan Laut Laksamana Madya TNI Marsetio, M.M pada Seminar dan diskusi "Rekonseptualisasi Pembangunan Daerah Perbatasan sebagai Beranda Depan NKRI," Seminar Prodi Kajian Budaya dan Media Sekolah Pasca Sarjana UGM, Yogyakarta 19 Desember 2011.

Undang Undang Dasar 1945. Jakarta: Balai Pustaka, 1991.

Undang-Undang Nomor 23 Tahun 2004 tentang Pemerintah Daerah

Undang-Undang Nomor 26 Tahun 2007 tentang Penataan Ruang.

Undang Undang Nomor 43 Tahun 2008 tentang Wilayah Negara

Peraturan Menteri Dalam Negeri Nomor 2 Tahun 2011 tentang Pedoman Pembentukan Badan Pengelola Perbatasan Di Daerah

Peraturan Menteri Pertahanan Nomor 10 Tahun 2010 tentang Tunjangan Operasi Pengamanan bagi Prajurit TNI dan PNS yang bertugas dalam operasi pengamanan pada pulau-pulau kecil terluar dan wilayah perbatasan.

Keputusan Menteri Kelautan dan Perikanan Nomor 5 Tahun 2008 tentang Usaha Perikanan

Peraturan Pemerintah Republik Indonesia Nomor 40 Tahun 2006 tentang Tata Cara Penyusunan Rencana Pembangunan Nasional.

Peraturan Kepala Badan Nasional Pengelola Perbatasan Nomor 1 Tahun 2011 tentang Desain Besar Pengelolaan Batas Wilayah Negara Dan Kawasan Perbatasan Tahun 2011-2025.

Peraturan Kepala Badan Nasional Pengelola Perbatasan Nomor 2 Tahun 2011 tentang Rencana Induk Pengelolaan Batas Wilayah Negara Dan Kawasan Perbatasan Tahun 2011-1014

Peraturan Kepala Badan Nasional Pengelola Perbatasan Nomor 2 Tahun 2011 tentang Rencana Aksi Pengelolaan Batas Wilayah Negara Dan Kawasan Perbatasan Tahun 2011

Peraturan Kepala Badan Nasional Pengelola Perbatasan Nomor 4 Tahun 2011 tentang Rencana Kerja Badan Nasional Pengelola Perbatasan Tahun 2011. 